\title{
A RICl atinge o seu oitavo ano
}

Caro leitor,

É com inúmeras satisfações que a Revista Ibero-americana de Ciência da Informação (RICI) lança o número relativo ao segundo semestre de 2015. Primeiramente, pelo fato de que a revista agora atinge o oitavo ano de publicação ininterrupta. Ter alcançado esse oitavo ano é um marco no contexto da Ciência da Informação pois, como comentava o nosso Mestre Edson Nery da Fonseca, os periódicos brasileiros sofriam do que ele denominou "doença dos sete". Isto é, muitos títulos nacionais não alcançavam essa marca, perecendo antes do sétimo ano!

A segunda satisfação sentida está relacionada ao cinquentenário do início do curso de graduação em Biblioteconomia da Universidade de Brasília. Curso este que, desde 1965, já formou centenas de bibliotecários e que, nos últimos anos, tem obtido a nota máxima na classificação do Guia do estudante (Editora Abril). Detalhes sobre os primeiros anos desse curso estão contidos no livro "Criação da Faculdade de Biblioteconomia da UnB, 1962-1967", disponibilizado em texto completo [URL: http://www.youblisher.com/p/977073-Criacao-daFaculdade-de-Biblioteconomia-da-UnB-1962-1967/].

A terceira satisfação foi gerada pelo fato de assumir, a partir do oitavo volume o honroso cargo de Editor da RICl. Este cargo foi anteriormente exercido com grande sucesso, pelo professor Fernando Cesar Lima Leite. Ao Professor Fernando agradeço o tempo dedicado nas tarefas executadas durante a passagem da editoria para a minha pessoa. Aqueles que militam na labuta editorial sabem que são inúmeros e importantes os detalhes que precisam ser conhecidos para que o trabalho de um editor seja realizado sem percalços.

A RICI foi criada em 2008, como

parte de um acordo bilateral visando conjugar esforços dos Programas de Pósgraduação em Ciência da Informação do Departamento de Ciência da Informação da Universidade de Brasília (CID-UnB) e do Departamento de Biblioteconomía y Documentación da Universidad Carlos III de Madrid nas áreas de pesquisa, ensino e atividades de intercâmbio acadêmico e científico (SIMEÃO, 2008).

O objetivo da RICl foi traçado em 2008 e, desde então, o seu foco tem por missão

promover a aproximação entre pesquisadores da Ibero -américa e de outras latitudes, para a troca de experiências, mediante a publicação de textos relevantes que espelhem as linhas de pensamento e ação, tanto no campo acadêmico quanto profissional e empresarial no âmbito dos sistemas de informação e documentação. (Idem, 2008)

Os seis artigos e um ensaio contidos no presente número são: 
1) "Preservação digital, recuperação da informação e linguagem", de Ernesto Carlos Bode e Renato Tarciso Barbosa de Sousa. O texto analisa as consequências de problemas de funcionamento em sistemas de recuperação da informação em longo prazo, em relação ao uso da linguagem nesses sistemas.

2) "Ações culturais em bibliotecas públicas municipais: estudo comparado das práticas de Goiânia (GO) e São Paulo (SP) ", de Laís Pereira de Oliveira, Josina da Silva Vieira e Gustavo Adolfo Lopes. $\mathrm{O}$ artigo aborda a realização de ações culturais em bibliotecas públicas municipais, pelo estudo comparado das práticas de Goiânia e São Paulo.

3) "A questão da privacidade no contexto da Ciência da Informação: uma análise das Teses e Dissertações do Programa de Pós-graduação em Ciência da Informação da UNESP campus de Marília", de Ana Paula Grisoto, Ricardo Cesar Gonçalves Sant'Ana, José Eduardo Santarem Segundo. O escopo do trabalho é investigar a questão da privacidade, sobre um olhar da Ciência da Informação e verificar sua atuação neste contexto.

4) "Produção e presença dos países do Caribe na base de dados Scopus sobre a temática da Documentação na Comunicação Social (1986-2013) ", de Jorge Caldera-Serrano. No artigo foram analisados os dados obtidos por meio da análise das publicações existentes na base de dados Scopus e os rankings gerados por esse instrumento pelo grupo de pesquisa Scimago sobre a produção dos diversos países do Caribe sobre a temática da documentação nos meios de comunicação. Foi feita uma comparação entre esses diferentes países bem como a análise da produção científica.

5) "A ação comunicativa e de informação: modelo transdisciplinar para o aprender a aprender", de Márcia Marques. Este artigo trata do Modelo de Ação Comunicativa e de Informação para Redes Sociais em Ambientes Digitais, uma articulação transdisciplinar de conhecimentos e saberes que orienta a construção coletiva e colaborativa de estratégias inclusivas de comunicação e de formação permanente de competências para promover o entendimento entre atores integrantes de uma rede social.

6) "Uma análise da rede social de tutores de comunidade em estado de vulnerabilidade social, nos aspectos de comunicação e tecnologia da informação", de Benedito Medeiros Neto, Eliandra Isys Sandes Silva, Marcella Pantarotto. A análise da rede social dos tutores universitários teve como objetivo identificar as atribuições e relações como mediadores, de aluno participantes de um curso de literácias, via dispositivos móveis, nas regiões administrativas de Itapoã e Paranoá, no Distrito Federal.

7) "Informação em rede e o direito à informação", de Juliana Fachin, Nelma Camelo de Araujo e Úrsula Blattmann. Essa reflexão apresenta a questão do direito à informação nas redes sociais, com base em autores interdisciplinares, nas áreas de sociologia, comunicação, administração e informação

Também foi retomada a divulgação das teses e dissertações defendidas no Curso de Pós-graduação em Ciência da Informação da Universidade de Brasília. Essa divulgação foi iniciada no volume 2, publicado em 2009, contemplando as defesas realizadas naquele ano. Infelizmente, essa divulgação não teve continuidade. Ela foi retomada no número anterior (v. 8, n.1), contemplando as defesas realizadas em 2010. No presente número estão incluídas as defesas relativas a 2011, incluindo 26 documentos. Vale a pena ressaltar que, além da 
referência bibliográfica e dos resumos (português e inglês), também foi incluído o link do documento para o Repositório Institucional da Universidade de Brasília. Assim, o leitor, poderá ter, de forma rápida, acesso ao texto completo da pesquisa realizada no âmbito da nossa pósgraduação.

Desejo uma ótima leitura e até o nosso próximo número!

Murilo Bastos da Cunha

Editor da RICl

\section{Referências}

SIMEÃO, Elmira. Apresentação. Revista Ibero-americana de Ciência da Informação, v. 1, n. 1, 2008. Disponível em: http://periodicos.unb.br/index.php/RICl/article/view/2050/2322 Acessado em: 10 de agosto de 2015. 